\title{
DESENTRALISASI SEBAGAI VARIABEL PEMODERASI HUBUNGAN ANTARA PARTISIPASI ANGGARAN TERHADAP KINERJA APARATUR PEMERINTAH DAERAH PROVINSI SULAWESI TENGAH
}

\author{
Olivia H. Munayang ${ }^{1}$, Fitriana ${ }^{1}$ \\ ${ }^{1}$ Dosen Jurusan Akuntansi Fakultas Ekonomi STIE Panca Bhakti Palu
}

\begin{abstract}
This research uses accounting science approach, especially public sector accounting. This study aims to examine the relationship between budgetary participation on apparatus performance by using decentralization as a moderating variable. The sampling method uses saturated or census sampling method. Analysis of the data used is moderating regression analysis. The data obtained from the results of giving questionnaires and direct interviews with respondents as many as 66 people. The results of this study indicate a significance value of $0.184>0.05$, so budget participation does not affect the performance of the apparatus. And the significance value of the interaction test is $0.438>0.05$, so budget participation does not affect the performance of the apparatus which is moderated by decentralization.
\end{abstract}

Keywords: Budgetary Participation, Decentralization, Apparatus Performance

\section{ABSTRAK}

Penelitian ini menggunakan pendekatan ilmu akuntansi, khususnya akuntansi sektor publik. Penelitian ini bertujuan untuk menguji hubungan antara partisipasi anggaran terhadap kinerja aparatur dengan menggunakan desentralisasi sebagai variable moderasi. Penelitian ini menggunakan metode sampel jenuh atau sensus. Analisis data yang digunakan yaitu moderating regression analysis. Adapun data didapatkan dari hasil pemberian kuesioner dan wawancara langsung dengan responden sebanyak 66 orang. Hasil penelitian ini menunjukkan nilai signifikansi $0,184>0,05$, sehingga partisipasi anggaran tidak memengaruhi kinerja aparatur. Sementara itu, nilai signifikansi uji interaksi 0,438>0,05, sehingga partisipasi anggaran tidak memengaruhi kinerja aparatur yang dimoderasi oleh desentralisasi.

Kata kunci: Partisipasi Anggaran, Desentralisasi, Kinerja Aparatur

\author{
Jurnal Akun Nabelo: \\ Jurnal Akuntansi Netral, Akuntabel, Objektif \\ Volume 1/Nomor 2/Jan 2019 \\ Jurusan Akuntansi FE-Universitas Tadulako
}

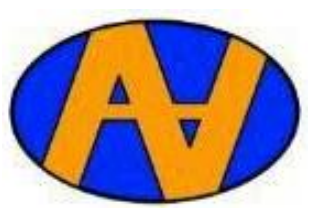




\section{A. PENDAHULUAN}

Penganggaran sektor publik merupakan instrumen akuntabilitas atas pengelolaan dana publik dan pelaksanaan program-program yang dibiayai dari uang publik. Penganggaran sektor publik terkait dalam proses penetuan jumlah alokasi dana untuk tiap-tiap program dan aktivitas dalam satuan moneter. Dengan dikeluarkannya Peraturan Pemerintah Nomor 17 Tahun 2005 tentang Perubahan atas PP No. 6/2005 tentang pemilihan dan pemberhentian Kepala Daerah dan Wakil Kepala Daerah membawa Indonesia pada titik dimana masalah peran pusat dan daerah masuk kembali pada wacana publik. Sentralisasi dan desentralisasi sebagai bentuk penyelenggaraan negara adalah persoalan pembagian sumber daya dan wewenang. Saat ini desentralisasi dikaitkan dengan pertanyaan apakah prosesnya cukup akuntabel untuk menjamin kesejahteraan masyarakat. Peningkatan kesejahteraan masyarakat merupakan salah satu tujuan utama dari perubahan sistem pemerintahan, dari sistem sentralistik menjadi desentralisasi. Sistem sentralistik memuat mengenai sistem pemerintahan dari pusat yang kemudian diterapkan di daerah-daerah. Sistem sentralistik, menyebabkan ketergantungan sehingga menyebabkan rendahnya kualitas maupun kurangnya kreativitas. Di sisi lain, sistem pemerintah yang telah menerapkan sistem otonomi daerah menyebabkan peningkatan dari segi kreativitas, serta tingginya kualitas pelayanan di pemerintah. Salah satu cerminan pemerintah dalam rangka peningkatan kualitas adalah penyusunan anggaran diserahkan kepada masing-masing pemerintah daerah.

Partisipasi anggaran merupakan tingkat seberapa jauh keterlibatan dan pengaruh individu didalam menentukan dan menyusun anggaran yang ada dalam divisi atau bagiannya, baik secara periodik maupun tahunan.
Munayang \& Fitriana

Anggaran Pendapatan dan Belanja Daerah (APBD) disusun berdasarkan pendekatan kinerja, yaitu suatu sistem anggaran yang mengutamakan upaya pencapaian hasil kerja dari perencanaan alokasi biaya yang ditetapkan. Berdasarkan pendekatan kinerja, APBD disusun berdasarkan pada sasaran tertentu yang hendak dicapai dalam satu tahun anggaran.

Kinerja merupakan gambaran mengenai tingkat pencapaian pelaksanaan suatu program kegiatan atau kebijakan dalam mewujudkan sasaran, tujuan, visi dan misi pemerintah atau organisasi yang dituangkan melalui perencanaan strategis suatu organisasi. Kemampuan sebuah pemerintah dalam mengelola suatu anggaran sangat dibutuhkan untuk meningkatkan kinerja pemerintah yang nantinya akan berdampak pada kesejahteraan masyarakat.

Pengukuran kinerja mencakup berbagai aspek sehingga dapat memberikan informasi yang efisien dan efektif dalam pencapaian kinerja tersebut. Sesuai dengan pendekatan kinerja yang digunakan dalam penyusunan anggaran, maka setiap alokasi biaya yang direncanakan harus dikaitkan dengan tingkat pelayanan atau hasil yang diharapkan dapat dicapai. Kinerja pemerintah daerah dapat diukur melalui evaluasi terhadap pelaksanaan anggaran. (Kepmendagri No 29 Tahun 2002).

Berdasarkan data yang ada, APBD Pemerintah Sulawesi Tengah mengalami kenaikan, pada tahun 2016 sebesar Rp 3.353 triliun atau sekitar 95,60\% naik menjadi $\mathrm{Rp}$ 3.638 triliun atau sekitar 96,35\% pada tahun 2017.

Kemajuan suatu bangsa salah satunya ditentukan oleh kemampuan aparatur birokrasi dalam menjalankan tugas dan fungsinya, yaitu sebagai pelayan publik kepada masyarakat secara profesional dan akuntabel. Kondisi ini akan berdampak pada kinerja dari aparatur birokrasi sesuai dengan harapan dari masyarakat, pada akhirnya akan timbul trust kepada aparatur birokrasi tersebut. 
Beberapa penelitian terdahulu telah membahas hubungan antara partisipasi anggaran dan kinerja aparatur, salah satu penelitian yang sejalan dengan penelitian ini adalah dilakukan oleh Agusti (2012) dengan judul Pengaruh Partisipasi Penyusunan Anggaran terhadap Kinerja Aparatur Pemerintah Daerah dengan Dimoderasi oleh Variabel Desentralisasi dan Budaya Organisasi (Studi Kasus pada Pemerintah Kabupaten Bengkalis).

Dengan mengacu pada pendekatan kontijensi, maka terdapat beberapa variabel yang dapat memengaruhi hubungan antara partisipasi anggaran dengan kinerja. Pendekatan kontijensi mengemukakan bahwa pengaruh partisipasi anggaran terhadap kinerja aparatur mungkin akan berbeda dari satu situasi dengan situasi lain. Pendekatan ini memungkinkan adanya variabelvariabel lain yang dapat bertindak sebagai faktor moderasi yang mempengaruhi hubungan antara partisipasi anggaran dan kinerja (Brownell, 1982).

Lebih lanjut (Davis, 1963; Derber, 1963; Strauss \& Rosenstein, 1970; Vroom, 1969), partisipasi anggaran seharusnya dapat sangat membantu sebuah organisasi meningkatkan kinerja. Bahkan Stone et al. (2000) menambahkan bahwa peran dari pengetahuan manajemen dalam mengelola suatu organisasi menjadi sebuah hal yang penting desentralisasi merupakan sebuah kebijakan yang mengharuskan pemerintah daerah memiliki sebuah kewenangan untuk mengelola daerah hingga proses penyusunan anggaran. Hal ini juga akan memberikan rasa tanggung jawab pada pegawai pemerintah daerah untuk menyusun anggaran. Penelitian ini juga akan dilakukan pada SKPD di Provinsi Sulawesi Tengah, mengingat ingin melihat kinerja aparatur pemerintah dengan melihat melalui anggaran yang disusun oleh SKPD tersebut.

Berdasarkan uraian fenomena tersebut kiranya menarik untuk diteliti. Pertama, apakah partisipasi anggaran memengaruhi kinerja aparatur pemerintah Sulawesi Tengah; Kedua, apakah partisipasi anggaran memengaruhi kinerja aparatur pemerintah Sulawesi Tengah jika dimoderasi oleh desentralisasi. Pada penelitian ini menggunakan teori kontijensi untuk melihat faktor-faktor yang dapat memoderasi hubungan antara partisipasi anggaran terhadap kinerja aparatur pemerintah daerah. Woods (2009) menambahkan bahwa adanya teori kontijensi yang digunakan pada penelitian, dapat mengetahui faktor-faktor yang dapat sistem dalam sektor publik.

Terkait pada penelitian ini, pendekatan kontijensi sangat dibutuhkan untuk melihat ketidakpastian lingkungan yang terjadi khususnya pada sektor publik. Adapun variabel kontijensi yang digunakan pada penelitian ini yang terkait dengan pengaruh partisipasi anggaran terhadap kinerja aparatur pemerintah, yaitu desentralisasi. Desentralisasi merupakan sebuah kebijakan atas pendelegasian wewenang yang diberikan kepada daerah atau bawahan guna penyusunan anggaran.

\section{B. TELAAH PUSTAKA}

\section{B.1 Partisipasi Anggaran}

APBD yang telah disusun memiliki peranan sebagai perencanaan dan sebagai kriteria kinerja, yaitu anggaran dipakai sebagai salah satu alat untuk mengukur kinerja. Untuk mencegah dampak disfungsional atas sikap dan perilaku anggota organisasi dalam penyusunan anggaran, diperlukan keterlibatan pegawai pada level yang lebih rendah. Oleh sebab itu, anggaran partisipatif dapat dinilai sebagai pendekatan yang dapat meningkatkan kinerja setiap anggota organisasi (Sardjito \& Muthaher, 2007).

\section{B.2 Desentralisasi}

Desentralisasi

$\begin{array}{lcr}\text { penyerahan } & \text { kewenangan } & \text { dari } \\ \text { pemerintah } & \text { pusat } & \text { kepada } \\ \text { pemerintah } & \text { daerah } & \text { untuk } \\ \text { mengurusi urusan rumah } & \text { tangga }\end{array}$


sendiri berdasarkan prakarsa dan aspirasi dari rakyatnya dalam kerangka negara kesatuan Republik Indonesia. Dengan adanya desentralisasi maka munculkan otonomi bagi suatu pemerintah daerah.

Desentralisasi pada saat ini telah menjadi azas penyelenggaraan pemerintahan yang diterima secara dengan berbagai macam bentuk aplikasi di setiap negara. Menurut Prasojo (2003) dalam Agusti (2012), penerimaan desentralisasi sebagai azas dalam penyelenggaraan pemerintahan disebabkan oleh fakta bahwa tidak semua urusan pemerintahan dapat dieslenggarakan secara sentralisasi, mengingat kondisi geografis, kompleksitas perkembangan masyarakat, kemajemukan struktur sosial, dan budaya lokal, serta adanya tuntutan demokratisasi dalam penyelenggaraan pemerintahan.

\section{B.3 Kinerja Aparatur}

Kinerja pemerintah dalam lingkup kajian organisasi adalah secara makro, tujuan, cita-cita, dan harapan suatu organisasi yang diusahakan pencapaiannya dan perwujudannya melalui organisasi tersebut. Sekelompok orang yang memiliki kesetiaan kepentingan juga diusahakan pencapaiannya melalui organisasi, sedangkan pada tingkat individu, berbagai tujuan, keinginan, cita-cita, harapan, dan kebutuhannya hanya bisa tersalurkan, terpenuhi, dan terpuaskan dengan menggunakan jalur organisasional. Adanya hubungan ketergantungan antara manusia dengan organisasi dalam arti bahwa manusia tidak mungkin lagi mencapai berbagai tujuannya tanpa menggunakan jalur organisasional dan sebagainya.

Mangkunegara

menyatakan kinerja berasal dari kata job performance atau actual performance (prestasi kerja atau prestasi sesungguhnya yang dicapai oleh seseorang). Pengertian kinerja (prestasi kerja) adalah hasil kerja secara kualitas dan kuantitas yang dicapai oleh seseorang pegawai dalam melaksanakan tugasnya sesuai dengan tanggung jawab yang diberikan kepadanya.

\section{METODE PENELITIAN}

Penelitian ini memfokuskan pada penjelasan secara ilmiah mengenai pengaruh variabel independen terhadap variabel dependen. Pada penelitian akan menemukan pengaruh partisipasi anggaran terhadap kinerja aparatur daerah Provinsi Sulawesi Tengah yang dimoderasi oleh desentralisasi. Populasi penelitian ini adalah aparatur SKPD Pemerintah Provinsi Sulawesi Tengah, dalam hal ini Kepala SKPD, Kepala Bagian Keuangan, dan Pejabat Penatausahaan Keuangan, yang berada dalam lingkup SKPD Pemerintah Provinsi Sulawesi Tengah. Dalam penelitian ini, sampel berjumlah 99 responden yang diambil dari 33 SKPD di Provinsi Sulawesi Tengah. Penentuan sampel tersebut dimaksudkan agar pemilihan responden adalah orang-orang yang terlibat langsung dengan laporan keuangan, sehingga responden yang dipilih adalah orang yang tepat. Penelitian difokuskan untuk menguji secara empiris pengaruh partisipasi anggaran terhadap kinerja aparatur pemerintah daerah Provinsi Sulawesi Tengah yang dimoderasi oleh desentralisasi. Penarikan sampel dilakukan dengan metode sampling jenuh atau sensus, serta data yang digunakan dalam penelitian ini adalah data primer yang langsung diperoleh dari responden. Teknik pengumpulan data menggunakan kuesioner, observasi dan interview terhadap responden. Pengujian akan dilakukan menggunakan regresi sederhana dan multiple regression analysis (MRA) atau uji interaksi yang dijabarkan dibawah ini : Model yang digunakan dalam penelitian ini disajikan dalam persamaan sebagai berikut:

Persamaan 1: $\mathrm{Y}=\mathrm{a}+\beta 1 \mathrm{X} 1+\varepsilon$

Persamaan $2: Y=a+\beta 1 X 1+\beta 2 X 1 X 2+\varepsilon$ 
Keterangan:

$\mathrm{Y}=$ Kinerja aparatur

$\mathrm{a}=$ Konstanta

$\beta=$ Koefisien regresi

$\mathrm{X}_{1}=$ Partisipasi anggaran

$\mathrm{X}_{2}=$ Desentralisasi

$\beta=$ Koefisien Beta

$\varepsilon=$ Standar Error

\section{HASIL DAN PEMBAHASAN}

\section{D.1 Pengaruh Partisipasi Anggaran terhadap Kinerja Aparatur Pemerintah Provinsi Sulawesi Tengah}

Pengujian permasalahan dan hipotesis pertama yang telah dirumuskan, dilakukan dengan uji t. Ringkasan hasil analisis menggunakan program SPSS dapat dilihat pada tabel 1. Hasil dari analisis regresi sederhana pada tabel 1. kemudian dimasukkan ke dalam model persamaan regresi dengan formulasi berikut:

$$
\begin{aligned}
& Y=a+\beta_{1} X_{1}+\varepsilon \\
& Y=46,252+0,145 X_{1}+\varepsilon
\end{aligned}
$$

Persamaan tersebut menunjukkan variabel bebas $\left(\mathrm{X}_{1}\right)$ yang dianalisis memberikan pengaruh terhadap kinerja aparatur SKPD. Berdasarkan data tersebut juga dapat diperoleh sebuah simpulan mengenai hasil pengujian hipotesis bahwa variabel partisipasi anggaran $\left(\mathrm{X}_{1}\right)$ diperoleh nilai signifikansinya kurang dari taraf ketidakpercayaan $\quad 5 \% \quad$ yaitu $0,184>0,05$. Nilai ini menunjukkan bahwa variabel partisipasi anggaran $\left(\mathrm{X}_{1}\right)$ tidak berpengaruh signifikan terhadap kinerja aparatur SKPD (Y). Berdasarkan hasil tersebut maka hipotesis pertama ditolak.

Hasil ini sejalan dengan penelitian sebelumnya yang dilakukan oleh Jeremias dan Setiawan (2008) dengan judul The moderating effects of hierarchy and control systems on the relationship between budgetary participation and performance. Walaupun hasilnya menunjukkan partisipasi anggaran mempengaruhi secara positif terhadap kinerja aparatur, namun variabel hierarchy menyebabkan terjadi pengaruh negatif hubungan antara partisipasi dan kinerja. Hal tersebut sama dengan hasil penelitian ini yang mengatakan bahwa variabel moderasi cost management knowledge dan desentralisasi menyebabkan pengaruh yang tidak signifikan antara partisipasi anggaran terhadap kinerja aparatur.

Hasil moderating regression analysis (MRA) tabel 3, kemudian dimasukkan kedalam model persamaan MRA dengan formulasi berikut:

$\mathrm{Y}=\mathrm{a}+\beta_{1} \mathrm{X}_{1}+\beta_{2} \mathrm{X}_{1} \mathrm{X}_{2}+\varepsilon$

$=30,557+0,811 X_{1}+0,575 X_{1} X_{2}+\varepsilon$

Hasil dari moderating regression analysis (MRA) pada tabel 3 menunjukkan desentralisasi dengan nilai signifikansinya 0,036 kurang dari 0,05 (signifikan) tapi secara uji interaksi tidak berpengaruh signifikan yaitu pada nilai 0,438 lebih dari 0,05 sehingga tidak dapat digolongkan sebagai variable moderating. Dapat dijelaskan bahwa variabel moderasi tidak bisa ditempatkan sebagai variabel prediktor, dengan demikian dapat disimpulkan bahwa hipotesis kedua ditolak.

Hasil penelitian ini sejalan dengan penelitian yang dilakukan oleh Locke et al. (1986) menemukan bahwa dengan adanya cost management knowledge dalam penyusunan anggaran maka dapat menyebabkan terjadinya overload information, sehingga dapat menyebabkan kinerja organisasi menurun dikarenakan dalam penyusunan anggaran informasi yang diperoleh lebih dari yang dibutuhkan sehingga dalam pelaksanaanya cenderung informasi yang dibutuhkan tidak digunakan dalam proses penyusunan anggaran. Sama halnya dengan penelitian yang dilakukan oleh Nor (2007) yaitu adanya interaksi antara partisipasi anggaran terhadap kinerja manajerial tidak memiliki hasil yang signifikan. Penelitian ini menjadi penting mengingat terjadi ketidakkonsistenan hasil penelitian terkait interaksi desentralisasi dengan hubungan antara partisipasi anggaran terhadap kinerja manajerial. 
Tabel 1

Hasil Uji Hipotesis Persamaan 1

\begin{tabular}{|l|c|c|c|c|c|c|}
\hline \multirow{2}{*}{ Variabel } & \multicolumn{2}{|c|}{$\begin{array}{c}\text { Unstandardized } \\
\text { Coefficients }\end{array}$} & $\begin{array}{c}\text { Standardized } \\
\text { Coefficients }\end{array}$ & \multirow{2}{*}{ T } & \multirow{2}{*}{ Sig. } & Keterangan \\
\cline { 2 - 7 } & B & Std. Error & Beta & & & \\
\hline (Constant) & 46.252 & 2.771 & & & & \\
Par. Anggaran & 0,194 & 0,145 & 0.165 & 1.342 & 0.184 & Tidak Signifikan \\
\hline
\end{tabular}

Sumber: Output SPSS, 2018

Tabel 2

Hasil Uji Hipotesis Persamaan 2

\begin{tabular}{|l|c|c|c|c|c|c|}
\hline \multirow{2}{*}{ Variabel } & \multicolumn{2}{|c|}{$\begin{array}{c}\text { Unstandardized } \\
\text { Coefficients }\end{array}$} & $\begin{array}{c}\text { Standardized } \\
\text { Coefficients }\end{array}$ & \multirow{2}{*}{ T } & Sig. & Keterangan \\
\cline { 2 - 7 } & B & Std. Error & Beta & & & \\
\hline $\begin{array}{l}\text { (Constant) } \\
\text { Partisipasi } \\
\text { Anggaran }\end{array}$ & 30,557 & 4.531 & & $-0,51$ & 0,960 & Tidak signifikan \\
\cline { 2 - 7 } & $-0,07$ & 0,131 & $-0,006$ & 4,618 & 0,000 & Signifikan \\
\hline Desentralisasi & 0,458 & 0,099 & 0,526 & & \\
\hline
\end{tabular}

Sumber: Output SPSS, 2018

Tabel 3

Hasil Uji Hipotesis Persamaan 3

\begin{tabular}{|l|c|c|c|c|c|c|}
\hline \multirow{2}{*}{ Variabel } & \multicolumn{2}{|c|}{$\begin{array}{c}\text { Unstandardized } \\
\text { Coefficients }\end{array}$} & $\begin{array}{c}\text { Standardized } \\
\text { Coefficients }\end{array}$ & \multirow{2}{*}{ T } & \multirow{2}{*}{ Sig. } & Keterangan \\
\cline { 2 - 7 } & $\mathbf{B}$ & Std. Error & Beta & & & \\
\hline (Constant) & 8,047 & 13,966 & & & & Tidak signifikan \\
\cline { 2 - 7 } X1 & 1,356 & 0,811 & 1,157 & 1,671 & 0,100 & Signifikan \\
\hline X2 & 0,676 & 0,315 & 0,777 & 2,146 & 0,036 & Tidak signifikan \\
\hline X1*X2 & $-0,014$ & 0,018 & $-0,575$ & $-0,78$ & 0,438 & \\
\hline \multicolumn{7}{|l|}{ a. Dependent Variable: Kinerja Aparatur SKPD } \\
\hline
\end{tabular}

Sumber: Output SPSS, 2018 


\section{E. PENUTUP}

\section{E.1 Kesimpulan}

1. Partisipasi anggaran yang merupakan variabel yang mempengaruhi kinerja aparatur pemerintah tidak berpengaruh secara signifikan. Hasil ini menjelaskan bahwa kepercayaan yang diberikan dalam pengelolaan anggaran tidak dapat meningkatkan kinerjanya. Hal ini dikarenakan dalam proses penyusunan anggaran sering terjadi konflik internal antar pejabat yang secara tingkat karir pangkatnya lebih tinggi tidak memberikan kepercayaan kepada pejabat yang pangkatnya lebih rendah seperti pendapat ataupun masukkan yang bisa jadi pertimbangan yang baik untuk instansi kedepannya.

2. Desentralisasi yang menjadi variabel moderasi dalam penelitian ini memperlemah hubungan antara partisipasi anggaran dan kinerja aparatur. Hal ini terlihat pada nilai signifikansinya 0,036 kurang dari 0,05 (signifikan) tapi secara uji interaksi tidak berpengaruh signifikan sehingga tidak dapat digolongkan sebagai variabel moderating. Dapat dijelaskan bahwa variabel moderasi dalam hal ini desentralisasi tidak bisa ditempatkan sebagai variabel prediktor.

\section{E.2 Keterbatasan}

Berikut ini beberapa keterbatasan yang kemungkinan dapat mengganggu hasil penelitian ini:

1. Penulis hanya memasukkan satu variabel moderating yang memoderasi hubungan partisipasi anggaran dan kinerja aparat pemerintah daerah, yaitu desentralisasi. Diduga masih ada faktor lain yang memoderasi hubungan partisipasi anggaran dan kinerja aparatur.

2. Penelitian ini merupakan metode survey menggunakan kuesioner tanpa dilengkapi dengan wawancara atau pertanyaan lisan. Padahal metode survey menurut Indriantoro dan Supomo (1999) dalam Sardjito dan Muthaher (2007) adalah pengumpulan data yang diperoleh secara langsung dari sumber data dengan menggunakan pertanyaan lisan dan tertulis.

3. Kesibukan responden seperti keluar kota, rapat, dan banyaknya tamu, membatasi ruang gerak penulis dalam berinteraksi langsung untuk melakukan wawancara dan pendalaman survey.

\section{E.3 Saran}

1. Para pejabat kepala dinas Pemerintah Provinsi Sulawesi Tengah hendaknya melibatkan seluruh kabag/kasubag ataupun pegawai lainnya yang memiliki kualifikasi dan berpengalaman dalam penyusunan anggaran.

2. Penempatan kualifikasi pendidikan (backround lulusan ekonomi) dapat dijadikan pertimbangan dalam penempatan aparatur (pejabat).

3. Konflik-konflik internal yang disebabkan tumpang tindihnya tugas dan wewenang dapat diminimalisir dengan peraturan yang tegas mengenai pemisahan tugas dan wewenang Pengguna Anggaran (PA), Kuasa Pengguna Anggaran (KPA), Pejabat Pembuat Komitmen (PPK), Pejabat Pengadaan dan Pejabat Pelaksana Teknis Kegiatan (PPTK) dalam pengadaan barang/jasa.

\section{DAFTAR PUSTAKA}

Agusti, Restu. 2012. Pengaruh Partisipasi Penyusunan Anggaran terhadap Kinerja Aparatur Pemerintah Daerah dengan Dimoderasi oleh Variabel Desentralisasi dan Budaya Organisasi (Studi Kasus pada Pemerintah Kabupaten Bangkalis). Jurnal Ekonomi, Vol 20. No 3, September 2012, pp. 115.

Keputusan Menteri Dalam Negeri Nomor 29 Tahun 2002 Tentang Pedoman Pengurusan, Pertanggungjawaban dan 
Pengawasan Keuangan dan Belanja Daerah, Pelaksanaan Tata Usaha Keuangan Daerah dan Penyusunan Perhitungan Anggaran Pendapatan dan Belanja Daerah.

Nor, Wahyudin. 2007. Desentralisasi dan Gaya Kepemimpinan sebagai Variabel Moderating dalam Hubungan antara Partisipasi Penyusunan Anggaran dan Kinerja Manajerial. Simposium Nasional Akuntansi X, pp. 1-27.

Peraturan Pemerintah Republik Indonesia Nomor 17 Tahun 2005 Tentang Perubahan Atas Peraturan Pemerintah Nomor 6 Tahun 2005 Tentang Pemilihan, Pengesahan Pengangkatan, dan Pemberhentian Kepala Daerah dan Wakil Kepala Daerah.

Sardjito, B. dan Muthaher. 2007. Pengaruh Partisipasi Penyusunan Anggaran terhadap Kinerja Aparat Pemerintah Daerah: Budaya Organisasi dan Komitmen Organisasi sebagai Variabel Moderating. Simposium Nasional Akuntansi X.

Stone, D., Hunton, J., dan Wier, B. 2000. Succeeding in Management Accounting Part 1: Knowledge, Ability \& Rank. Accounting, Organizations and Society, Vol. 25, pp 697-715.

Undang-undang Nomor 23 Tahun 2014 tentang Pemerintah Daerah.

www.Sultengprov.go.id www.palu.bpk 